Article

\title{
Addressing Education for Sustainable Development in the Teaching of Science: The Case of a Biological Sciences Teacher Education Program
}

\author{
Deirdre Hogan ${ }^{1,2, *}$ and Joanne O'Flaherty ${ }^{1,2}$ (I) \\ 1 School of Education, University of Limerick, V94 T9PX Limerick, Ireland; joanne.oflaherty@ul.ie \\ 2 Ubuntu Network, University of Limerick, V94 T9PX Limerick, Ireland \\ * Correspondence: deirdre.hogan@ul.ie
}

check for updates

Citation: Hogan, D.; O'Flaherty, J. Addressing Education for Sustainable Development in the Teaching of Science: The Case of a Biological Sciences Teacher Education Program. Sustainability 2021, 13, 12028. https:// doi.org/10.3390/su132112028

Academic Editor: Jin Su Jeong

Received: 6 September 2021

Accepted: 25 October 2021

Published: 30 October 2021

Publisher's Note: MDPI stays neutral with regard to jurisdictional claims in published maps and institutional affiliations.

Copyright: (c) 2021 by the authors. Licensee MDPI, Basel, Switzerland. This article is an open access article distributed under the terms and conditions of the Creative Commons Attribution (CC BY) license (https:/ / creativecommons.org/licenses/by/ $4.0 /)$.

\begin{abstract}
Education plays a key role in ensuring that all learners are equipped with the knowledge and skills needed to promote sustainable development. The United Nations Sustainable Development Goals (SDG) set out the key challenges of our time with targets to protect the planet, end poverty, and improve the prospects of all people by 2030. As global challenges including access to healthcare and climate change escalate, the need for action is even more pressing. Education is an enabler of change and presents opportunities to support learners to explore how they can participate in transformative education experiences that focus on building a more sustainable world. Science education provides unique opportunities to explore sustainability given the nature of the discipline, the knowledge it reflects, and its focus on inquiry based pedagogical approaches. This study explores the nature of science as an academic discipline, as it is lived and perceived within the teaching of an undergraduate Science Education (biological sciences) program in a Higher Education Institution (HEI) and its capacity for the integration of Education for Sustainable Development (ESD). An ethnographic informed research design was adopted to document the social culture, perspectives, and practices inherent in the educational setting. Semi-structured interviews were conducted with academics and tutors from the HEI's Science Department who contribute to the program $(n=11)$. Focus groups were held with pre-service teachers enrolled on the program $(n=21)$ and observations from lectures, laboratory sessions, and field trips were carried out. Findings arising from analysis of data point to a strong link between science and society in science education, and the need for learners to develop critical scientific literacy that enables them to meaningfully navigate the multiple perspectives presented in media and public debates relating to sustainability issues. Findings suggest that while sustainability themes permeated some modules in the program, the emphasis was on imparting hard, technical knowledge rather than allowing for the critical exploration of issues. Results also highlight some discipline specific challenges to adopting discursive pedagogical approaches in the science education program. Some ways of understanding these findings are explored.
\end{abstract}

Keywords: science education; education for sustainable development; socio-scientific issues

\section{Introduction}

Internationally, the drive to address sustainability and inequality issues arising from development has been ongoing for some time [1-4]. The UN Sustainable Development Goals 2015-2030 (SDGs) lay out 17 critical challenges to a more sustainable future, including climate change, poverty, health, energy provision, and equality. The goals are promoted as being universal [5], with their principles, standards, and values applicable to all people in all countries [6]. The UN recognises that education is a central component for achieving the SDGs. While education and training permeates all the goals, as a sub-target of the ambitious SDG Goal 4 on Education, Target 4.7 emphasises the importance of education for sustainable development (ESD), stating that by 2030, countries must "ensure that all learners acquire the knowledge and skills needed to promote sustainable development, 
including, among others, through education for sustainable development and sustainable lifestyles, human rights, gender equality, ... global citizenship and appreciation of cultural diversity and of culture's contribution to sustainable development" [7] (p. 19). Given the complexity and interconnectivity of sustainability issues, all academic disciplines and educators can play a role in building the critical consciousness [8] of students and teaching for sustainability. Embracing this vision ensures a wider, interdisciplinary approach to teaching for sustainability, but also requires that educators have the capacity to pull together the disciplinary and pedagogical approaches that form a comprehensive ESD offering [9].

Opportunities exist within the teaching and learning of science to support students to engage and reflect upon global issues through the lens of science. Teachers of science and teachers of pre-service science teachers have a responsibility to ensure that ESD features strongly in their teaching. They also have a responsibility to ensure that science education affords students the space to reflect upon sustainability issues in a scientific way, with a particular focus on scientific inquiry, evidence-based learning, and engagement in socioscientific debate. Many of the core concepts and methods in science align closely with development and the SDGs. Scientific areas in the biological sciences such as immunology, medicine, ecology, genetics, horticulture, and agriculture provide an important context and basis for considering development issues. They also offer the potential to explore both social and scientific perspectives relating to key global challenges of our time. Scientific approaches to thinking and inquiry build important skills for interrogating sustainability issues. The authors argue that pre-service teachers must be supported to explore the links between science and society using discursive pedagogical approaches with a view to developing critical scientific literacy for sustainable development. Therefore, this study explores the nature of science as an academic discipline as it is lived and perceived within the teaching of an undergraduate Science Education (biological sciences) program in a Higher Education Institution (HEI) and its capacity for the integration of ESD. More specifically, it seeks to understand the relationship between science and society in the context of biological science teacher education and the integration of ESD. The study is framed by the following research question-how does the relationship between science and society, in the context of the Science Education (biological sciences) program, support and/or challenge the integration of ESD? In the next sections, we set the context for this study discussing the nature of science as an academic discipline, and surmise some of the contemporary goals of pre-service science teacher education programs that may be in and of themselves, supportive of the integration of ESD themes. We briefly discuss and synthesise ESD from the perspective of its philosophical and paradigmatic alliances with science as an academic discipline. The methodology is described and findings are presented. Finally, the authors discuss the findings from the perspective of critical scientific literacy.

\section{Science as an Academic Discipline}

From a social perspective, academic disciplines are distinguishable by the social culture and identity that develops within the group [10,11]. Being a member of a disciplinary group involves "a sense of identity and personal commitment, a "way of being in the world', a manner of taking on 'a cultural frame that defines a greater part of one's life'" [10] (pp. 24-25). Becher [12] emphasises the distinctive cultural characteristics of academic disciplines and the importance of recognizing this in research in higher education. Science emerged as an academic discipline from the Scientific Revolution, having utilitarian goals it became increasingly integrated into society [13]. It became embedded in social practices through activities such as the publication of research, public accreditation of experimental results, academic progression on the basis of research reputation, and the award of prestigious prizes for scientific discoveries [14]. Being socialised as an academic scientist involves entering the "tribe" of the discipline or sub-discipline and conforming to the "unspoken rules", norms, or traditions [14]. These are not listed or enforced by specific sanctions, rather they are incorporated as an ethos into the "scientific attitude" of the institution [14] (p. 30). Science may be described as the pursuit of knowledge to 
reliably explain the natural world $[15,16]$ or, more specifically, an attempt to understand, explain, control and predict the world we live in by using distinctive methods of enquiry, including experiments, observation and theory construction [17-19]. In science, knowledge is evidence based, generated through rigorous scientific processes, and tested for reliability. It claims objectivity, created without the influence of factors such as individual perspectives, value judgments, community bias or personal interests [20]. Some degree of subjectivity must be acknowledged however, owing to human choices and attitudes in scientific reasoning and inference [21]. Scientific knowledge is tentative but is also durable [22]. While it is subject to change in lieu of additional information and new ways of thinking, once it has undergone a significant degree of scrutiny it is generally accepted [18].

Science has diverged into sub-disciplines [23,24] with each sub-discipline considering an aspect of science on which it reports from its particular stance, using specific discourse [14] and instrumentation [25]. Scientific knowledge is derived from collective observations, experiments, trials and tests, and the hypothesizing and theorizing of individuals and scientific communities worldwide. Science is communicated through publication which is an expectation in scientific knowledge creation [26]. Academic disciplines differ in terms of the nature of associated knowledge, pedagogical approaches adopted, student experience, assessment types/modalities, problems studied, research methods used, types of generalizations made, and how outcomes are communicated [27]. While the natural sciences may be generally classified as 'hard' and 'pure' [10,28], Valiela [29] distinguishes between basic and applied science-basic science being concerned with description and explanation and applied focusing on prediction and control. The nature of science as an academic discipline and how this translates into teaching and learning contexts, has implications for how it is experienced by the learner in higher education and in schools. In the next sections, the authors surmise some of the contemporary developments in pre-service science teacher education: the development of scientific literacy; teaching socio-scientific issues; key pedagogical approaches used within the teaching of science and the concept of ESD as it relates to science education.

\subsection{Scientific Literacy}

Scientific literacy reflects a diversity of positions, descriptions and interpretations of the desired outcomes of science as an academic discipline [30-33]. It broadly comprises three areas of knowledge - content, procedural, and epistemic [18,34,35]. Content knowledge is described as knowledge of scientific theories and facts; procedural knowledge as knowledge of practices and procedures used by scientists to establish, report on and communicate scientific knowledge, based on empirical enquiry; and epistemic knowledge as an understanding of the role of specific constructs and defining features in establishing accepted scientific knowledge; for example, observations, theories, hypotheses, argumentation, methods of scientific enquiry, and the role of peer review [34]. Bybee's [36] competence model for scientific literacy, which is widely accepted [37], emphasises the importance of moving beyond learning about concepts and procedural methods to interrogating additional perspectives including the nature of science (NOS) and the role of science and technology in an individual's personal life and society. In this regard, scientific literacy comprises an understanding of socio-scientific issues that enable the learner to build an understanding of NOS and the role of science in personal life and society [36,38-41]. It requires the application of scientific knowledge in decision-making about personal and society-based situations [42]. Holbrook and Rannikmae describe the need to prepare students for the type of scientific literacy necessary for responsible citizenship. They use an approach called "education through science", rather than "science through education", [43] (p. 1348). Zeidler et al. [39] goes so far as to say that any conceptualization of scientific literacy falls short if it does not include ethical considerations, moral reasoning and character. Liu, Lin, and Tsai suggest in order to support learners' scientific literacy, science teachers need to demonstrate an understanding of the complex interactions of science, technology and society and also support students' engagement with socio-scientific issues [44]. In 
Ireland, where this study is set, the National Council for Curriculum and Assessment (NCCA) describe scientific literacy within the second level education system as enabling the learner to contribute to political, cultural and social life as thoughtful and active citizens, who appreciate the ethical and cultural values of science, and can therefore make informed decisions about local, national, and global challenges [45].

\subsection{Addressing Socio-Scientific Issues in Science Education}

Many approaches in science education recognise the role that science and technology play in society and the wellbeing of people and the planet [46-48]. One of the primary purposes of science education is a focus on the development of the learner's critical thinking and decision-making skills about controversial issues [49], where students are taught to be 'critical consumers of scientific knowledge' [50] (p. 8). In the 1970s, Science-Technology-Society (STS) was introduced into science education curriculum in the United States [36,51-53]. Its aim was to give students "knowledge about the science/society interface and the ability to make decisions about science-related social issues" [38] (p. 588). More recently, the practice of teaching via controversial topics and Socio-Scientific Issues (SSI) has been recognised internationally as an important addition to curriculum [54,55]. Socio-scientific issues (SSI) are contested and described as invoking economic, educational, ecological, cultural, aesthetic, moral, and religious values [56-59]. Zeidler et al. define SSI "as a developed pedagogical strategy" [39] (p. 360) that draw upon both social and scientific factors to address real-world problems. They are often controversial, require ethical or moral considerations, and are without clear solutions $[47,54,55]$. Cinici suggests that the teaching of socio-scientific issues (SSI) requires the interaction of social, ecological, economic, and biotechnological issues, all of which aid students to develop a scientific perspective [57]. Through engaging with SSI, learners are scaffolded to discuss controversial issues, and acknowledge the multi-dimensional nature of these issues drawing upon economic, ethical, political, and social lens [39,60,61]. Therefore, students are presented with opportunities to reflect critically on their own values and positionality $[42,46,62,63]$. Previous research highlights the importance of SSI in improving learners' critical decision-making and argumentation skills by providing students with social dilemmas which include scientific features [59,64-66]. Teachers of SSI need to draw upon knowledge across a number of domains as well as acknowledge the societal aspects of science. Thus, teacher educators need to consider and focus on the pedagogical implications of teaching socio-scientific issues [58]. Discourse-based pedagogies are emphasized as a means for students to practice negotiations of SSI and explore divergent perspectives on the issues [67], thus seeking to deliver a curriculum in "which scientific knowledge does not end up in isolated, artificial settings such as tests, but leaves sustainable traces in students' daily lives" [68] (p. 2765).

\subsection{Key Pedagogical Approaches Used within the Teaching of Science}

In order to support the development of scientific literacy and exploration of socioscientific issues, many studies have advocated the inclusion of active learning approaches in the teaching of science [69-71]. Erduran and Dagher [72] emphasise that in teaching students of science, "the aim should be to involve them in the practice of designing investigations and understanding methodological options that scientists use to address relevant questions" [72] (p. 105). Active learning engages the learner in "a complex set of intellectual, social and emotional processes that eventually lead to knowledge acquisition, meaning making, ownership of learning, and achieving higher levels of conceptual and epistemic understanding" [73] (p. 36). Equally the promotion of inquiry-based learning, an action-oriented instructional strategy, can be particularly effective in the teaching of science [74-76]. Scientific inquiry is described as the development of scientific knowledge by combining scientific processes (such as observing, predicting, questioning, measuring, interpreting and analysing data) with scientific knowledge, scientific reasoning, and critical thinking [42]. Inquiry-based learning in science education is modelled on the authentic 
inquiry processes of scientists [77]. The students learn by doing science. They are encouraged to ask scientifically oriented questions, seek out and use evidence to respond to the question, devise explanations from the evidence, connect the explanation to scientific knowledge, and communicate their findings while providing appropriate justification [74] Inquiry-based learning can be structured around pedagogical approaches such as problembased learning (PBL) which aligns particularly well with the aims of science education [78]. In this case students work collaboratively to seek solutions to carefully selected problems that are authentic, engaging and relevant to them and the real world [79]. Key outcomes can include problem solving, the development of critical knowledge, and the learner becoming self-directed and self-regulated [80,81]. Gallagher et al. [78] (pp. 139-140) outline a procedure for implementing a science problem-based learning experience (SPBLE), using a case study with an environmental problem at its core.

The skill of argumentation is central to decision-making in science [62]. Driver et al. [82] present a case for argumentation to be included in science education, to enhance scientific literacy, while Jiménez-Aleixandre [83] describes the purpose of argumentation in science education as enhancing knowledge about the nature of science, while also developing citizenship and higher order thinking skills. To demonstrate the socially constructed nature of scientific knowledge and the implications of science in society, the learner must be exposed to competing claims and supported to present coherent arguments evidencing their understanding of how decisions are constructed [82]. Argumentation is beneficial in terms of interpreting, constructing, and defending scientific explanations [84-86], and understanding the connections between science and social issues [42,87-89]. In order to address the problem, the learning environment must facilitate interaction to support reasoning and to facilitate the sharing of learning and conclusions, both of which are based on discussion. Students can have difficulty constructing well-developed arguments in relation to controversial socio-scientific issues (SSI) when explicit instruction is not provided, resulting in arguments that require further evidence and consideration of other perspectives [90].

\subsection{Education for Sustainable Development in Science Education}

Addressing issues related to sustainability and citizenship are now considered an important element of science education, and increasingly included in science curricula [62,91]. A central aim of science education is to teach students to be critical thinkers and participatory citizens who are capable of making well-informed and systematic decisions [62]. ESD supports the development of knowledge, skills, values, and attitudes that facilitate learners to make informed decisions, lead healthy lives, and respond to local and global challenges that enable a more sustainable and just society $[92,93]$. ESD uses an integrated and balanced approach when considering the interlinking social, economic, and environmental aspects of sustainable development $[4,92,94]$, requiring the learner to approach complex situations from a sustainable perspective. This educational experience requires learners to have both a local and a global dimension to their knowledge base: an understanding of international issues, an awareness of local issues, an ability to see the connection between the two, and to respond as global citizens. It is based on local needs, conditions and perceptions, but recognises that in order to fulfil local needs one must also consider global consequences and effects [95]. It reflects a philosophy of lifelong learning and forms an integral part of quality education [96]. ESD explores a wide range of global development challenges with huge variation in content and themes [97]. It straddles environmental, economic, social and cultural spheres and addresses issues such as health, wasteful consumption, conflict, poverty, environmental degradation, gender inequality, population growth, and the violation of human rights. It seeks to promote justice, citizenship, peace, ethics, environmental protection, democracy and good governance, security, equity, improved health in populations, universal education, an appreciation of cultural diversity, sustainable production and consumption, sustainable rural and urban development, natural resource management and preservation of biological and landscape diversity $[4,98,99]$. 
Many issues addressed within ESD draw upon scientific knowledge and understanding, particularly in relation to production and consumption, health, climate change and environmental protection, and as such can be aligned with science education. ESD emphasises the development of key skills such as critical thinking, information processing and communication, to support the learner to construct responses to local and global development issues and debates $[97,100]$. Wiek et al. [101,102] identify six sustainable competences that can empower students to address sustainability problems and foster sustainable development-systems thinking, futures thinking (anticipatory competence), values thinking (normative competence), strategic thinking (action-oriented competence), collaboration (interpersonal competence) and integrated problem-solving. UNESCO [103] added to this framework by including critical thinking competence and self-awareness competence.

Similar to the aims and purposes of science education, ESD demands a learner-centred approach, where the students are autonomous learners, building upon their own experiences and social contexts to develop their knowledge on sustainability issues [92]. Learner-centred approaches in ESD imply that educators act as facilitators of learning, rather than as experts who transfer structured knowledge, therefore enabling learners to address issues of sustainability and to make clear decisions for action that are culturally appropriate and locally relevant $[4,82,100,104,105]$. Many consider ESD to require a paradigm shift in education [106-109]. Sterling emphasises that ESD is not merely an addition to the curriculum, but rather a different view of curriculum (content, pedagogy, assessment), requiring changes in organizational policy and ethos [110]. Eilks [111] notes that in higher education, sustainability can be confined to the related scientific background and/or subject matter content. Eilks [111] draws on Burmeister et al. [112] and their review of science education literature pertaining to the integration of ESD and identifies four distinct models. The first relates to adopting principles from sustainable practices into laboratory-based science; for example, minimizing the use of environmentally harmful substances. The second is adding sustainable science as content in the science curriculum; for example, how science can contribute to sustainability. The third is using controversial sustainability questions for the SSI-driven science education; for example, having a debate on the use of biofuels. The fourth is using science education to inform a whole-school ESD approach; for example, exploring how science can contribute to a more sustainable school. Having examined science as an academic discipline and ESD in the literature, this study set out to explore the nature of science as an academic discipline and its capacity for the integration of ESD.

\section{Methodology}

The context for this study, is a level 8, four-year undergraduate science education (biological sciences) program that prepares students to teach science and biology in second level schools. It is a concurrent teacher education program where students study both science and education including foundation disciplines (psychology, philosophy, sociology and curriculum). At the time of sampling, it was one of two such programs available in the Republic of Ireland. The study is framed by the following research question: how does the relationship between science and society, in the context of the Science Education (biological sciences) program, support and/or challenge the integration of ESD? An ethnographicinformed research approach was adopted for this study. Research was conducted "in the field" [113] (p. 3). The research setting spanned the work/research spaces of teacher educators as well as the educational spaces in which they taught including lecture halls, laboratories and field-trip locations. This afforded a richness of opportunity in which participant observation could be undertaken and the generation of a "rich understanding of social action and its subtleties in different contexts" [114] (p. 512). It also allowed the researcher to socialise into the "rules, rituals, practices, beliefs, activities, organizations and daily life schedules" of the teacher educators at the centre of the study [115] (pp. 1-2). As full participation observation in a social setting was not viable as part of this ethnographicinformed study, the data collection focuses primarily on interviews with academics and 
teaching assistants from the HEI's Science Department who lead modules on the Science Education (biological sciences) program [116]. Modules are units of learning delivered over a 15-week period and typically comprise three lectures and associated laboratory sessions each week. It is important to note that these modules were taught to pre-service teachers registered on the science teacher education program as well as students registered on other science programs, for example, food science, and environmental science. While these faculty members supported science teacher education programs within the university through their engagement with these modules, they were hired in a science department to primarily support other science related programs. Notwithstanding this, we refer to them as 'teacher educators' in this paper. This group is responsible for shaping the biological science-based teaching and learning experience of pre-service teachers. The institutional research board granted ethical approval for the study. All participants provided informed consent prior to data collection and pseudonyms were used to maintain confidentiality.

\subsection{Methods and Participants}

Semi-structured interviews: The primary target group for the research was teacher educators in the Science Department at a university in the Republic of Ireland, all of whom were involved in the delivery of biology-related modules included on the science teacher education (biological sciences) program. Initial access to the group was secured through meeting with the Program Director. Interviews were an important research method for this research, allowing the researcher to gain in-depth information across a range of topics, and offer teacher educator participants a chance to shape and explain their views on science as an academic discipline [117]. Of the 10 lecturers involved in delivery of biological sciences modules, nine volunteered to take part in one or more semi-structured interviews. This included the Program Director. In addition, two teaching assistants were interviewed. In total, 19 semi-structured interviews were conducted with 11 participants. Table 1 below details the list of interview participants. Interview participants were responsible for leading a variety of biological science modules including General Microbiology, Plant and Animal Physiology, Diversity of Organisms, and Agriculture.

Table 1. Interview participant titles and biological sciences modules taught.

\begin{tabular}{|c|c|}
\hline Interview Participant Title & Biological Sciences Modules Taught \\
\hline Lecturer & General Microbiology \\
\hline Lecturer & $\begin{array}{c}\text { General Biology; Pollution Biology; Diversity of } \\
\text { Organisms; Genetic and Molecular Biology; } \\
\text { Plant and Animal Physiology }\end{array}$ \\
\hline Lecturer & Soil Science \\
\hline Lecturer & Soil Science \\
\hline Lecturer & Science Pedagogy 1 \\
\hline Lecturer & Agriculture 1, Agriculture 2 \\
\hline Lecturer & Vertebrae structure \& function \\
\hline Lecturer & General Biochemistry \\
\hline Teaching Assistant & $\begin{array}{c}\text { Genetic and Molecular Biology; Plant and } \\
\text { Animal Physiology }\end{array}$ \\
\hline Teaching Assistant & Agriculture 1, Agriculture 2 \\
\hline Lecturer and Program Director & Subject Pedagogies 2 \\
\hline
\end{tabular}

The purpose of the interviews was to yield an insight into how participants viewed, lived and communicated science (biology). Interviews also explored the values held by participants in relation to their work, science and research. The format for the semi-structured interviews followed an "interview guide" [116] (p. 438), which outlined questions and topics to be addressed, while also allowing for flexibility in how participants responded. Open-ended questions were used. The list of questions designed for the interviews was reflective of Schein's [118] levels of culture and other literature pertaining to understanding 
culture, disciplines and the NOS. Question categories spanned, knowledge associated with science (for example, tell me about your area within science? What is the essence of biology? What is it about? How is knowledge formed? What knowledge do you consider fundamental? What approaches to thinking are important?); norms and practices associated with science (for example, what do biologists do in the laboratory, in fieldwork? What are the practices and techniques that you use from day to day?); values and attitudes associated with science (for example, what do you value as a scientist? what makes a good biologist? what do you enjoy about your discipline?); science in society and influencing factors (for example, does biology contribute to the overall good? Do ethical issues arise? How valuable are scientific findings to society? Are there any examples within your own area where scientific claims resulted in positive/negative societal outcomes? Does it make you question the use of science to influence society?). The duration of each interview was approximately $45 \mathrm{~min}$ and was audio recorded for accuracy. Member-checking, where transcripts were returned to participants for review, allowed the researcher to improve upon the accuracy of the data collected.

Participant Observation: Participant observation was used to develop an understanding of the experiences and culture represented in the teaching and learning environments in which teacher educators operated and pre-service teachers occupied. Eleven observations were conducted in laboratories, lectures, and field trips. A framework for observation was derived from Morrison's [119] (p. 457) four levels of observation, spanning the physical setting, human setting, interactional setting and program setting. It also reflected elements from Spradley's [120] descriptive question matrix including actors, space, time, activities, objects, language, events, and goals. These were chosen, as they resonated with Schein's [118] levels of culture model, particularly at the level of "artefact". Shein [118] describes an artefact as all the phenomena that one sees, hears, and feels when coming into contact with a new group with an unfamiliar culture. The observation models chosen allowed for a series of questions to be compiled and used by the researcher to capture experiences in the teaching and learning spaces. These are reflected in Table 2 below.

Table 2. Research Observation Framework.

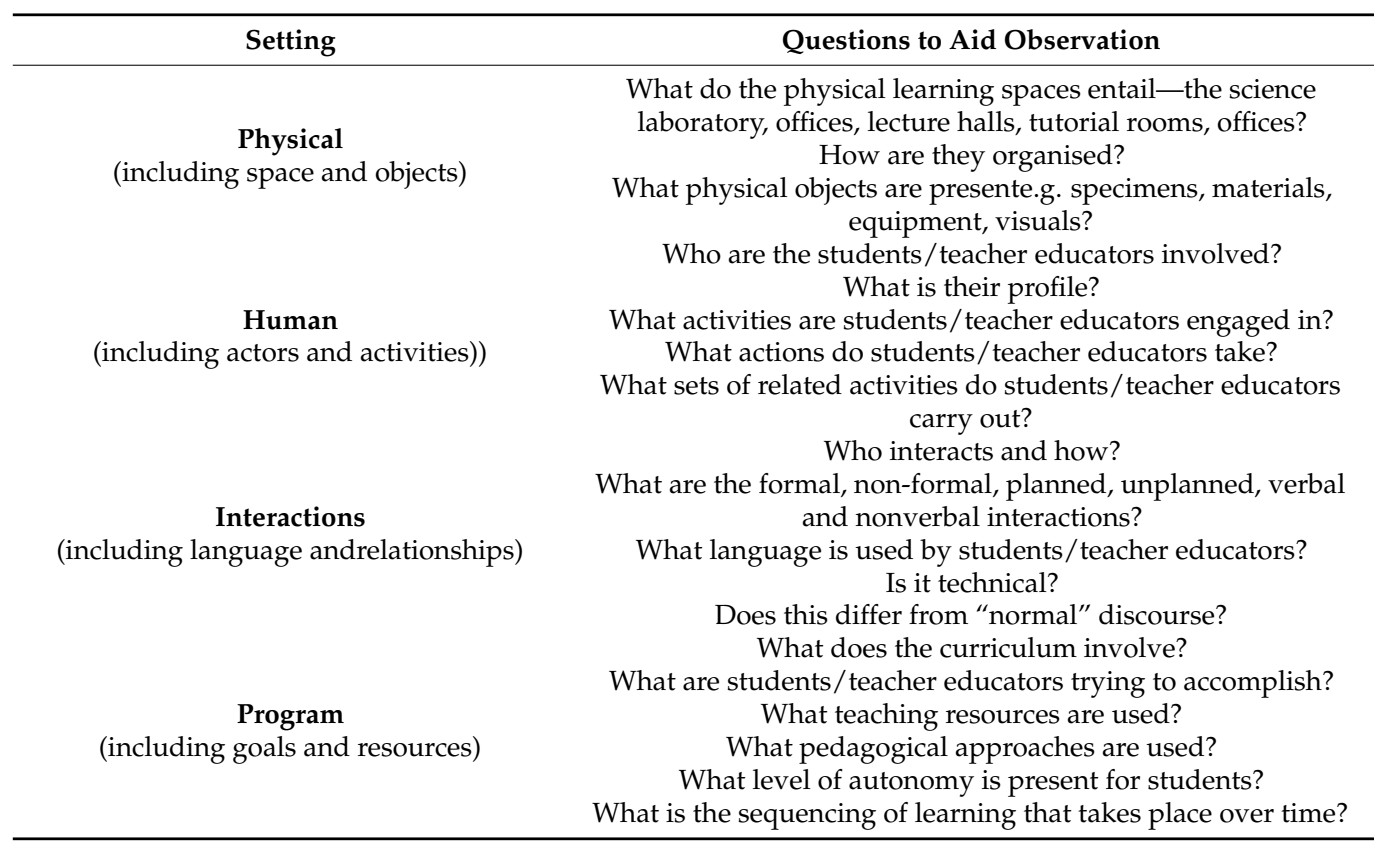

Questions prompted the researcher to observe both the pre-service teachers and teacher educators in a structured and consistent format. Note-taking was conducted in tandem with observation, and these accounts were subsequently used as a source of data [116]. 
Focus Group: The secondary target group for the research was pre-service teachers. This group was preparing to teach science at lower second level education and biology at upper second level. Three focus groups were conducted with undergraduate science education pre-service teachers. Focus groups comprised six to eight students in the third year of a four-year concurrent Science Education (biological sciences) program. Each focus group lasted for 35-40 min and was audio recorded for accuracy. Questions were openended and provided students an opportunity to share their experiences. The purpose of the focus groups was to gain an understanding of how science as an academic discipline was experienced by students. Students were asked to describe significant aspects of their experience to date and to give their views on the integration of ESD into their program. Questions focused on three areas: (1) their experiences of the science program (for example, why do you think science is important as a subject? How do you experience the program?); (2) their experiences of learning science on the program (for example, what kind of contemporary issues does science relate to? What issues are you particularly interested in? Why are you interested in these issues?); (3) their views on ESD as it relates to science education (for example, what is your understanding of ESD? What is your view of the role of ESD in science?).

\subsection{Data Analysis}

Drawing upon an ethnographic-informed research design, the researchers sought to make sense of the data and interpret it from within the cultural context of the research environment. They responded and adapted to data as it emerged, sought clarification, confirmed accuracy and explored particular lines of enquiry. The qualitative researcher is open to unusual or unexpected responses from subjects and adapts questioning and analysis to account for this. Their insights and interpretation determine the quality of the analysis [121-123]. Data were analysed using Braun and Clarke's six phase inductive thematic data analysis framework; familiarization with the data, generating initial codes, search for themes, review of themes, definition and naming of themes and writing the report [124], therefore identifying common themes, patterns or categories that transcend and emerge from the data [122]. Transcripts from interviews, focus groups and participant observation notes were read, themes noted, answers were classified and organised in line with emerging codes and themes and the original research question before gathering examples of these themes from the text [125]. Themes emerged by means of bottom-up coding and indexing, therefore, providing opportunities for new themes to emerge from the data [126]. Analysis of data involved iterative reviews, categorizing and coding, and resulted in the emergence of key themes. A random sample of the data was selected for review of the initial coding scheme. Multiple coders facilitated a reliable application of the coding scheme.

\section{Findings}

This study set out to explore the nature of science as an academic discipline as it is lived and perceived within the teaching of an undergraduate science teacher education (biological sciences) program and its capacity for the integration of ESD. Specifically, it sought to develop an understanding of the relationship between science and society in the context of science education and the opportunities for integration of ESD. Three major themes emerged from the data in response to the primary research question: developing scientific literacy for engagement in socio-scientific issues; barriers to discursive pedagogies in science teacher education; and sustainability in existing science education modules.

\subsection{Developing Scientific Literacy for Engagement in Socio-Scientific Issues (SSI)}

In this study, teacher educators spoke of the inextricable relationship between science and society, including discussion of scientific advances, scientific practices, scientific knowledge informing public debate, ethical considerations and dissemination of scientific information. They noted how scientific advances "have brought about improved living standards across 
the globe" (Teacher Educator 3) and provided examples from within their scientific areas of study, including the development of vaccines for human diseases, the fortification of foods to improve diets, the rejuvenation of polluted lands for agricultural or recreational use, the detection of illnesses, the recycling of waste, and the production of green energy to combat climate change and pollution. They also noted that science applications can have unintended consequences and unforeseen long-term effects. Microbial resistance to antibiotics was used by an interview participant as an example to illustrate this:

Consider bacterial resistance to antibiotics having risen from over prescription ... While early pioneers have contributed enormously to health ... we now have the issues of resistance to antibiotics and bigger and more mighty organisms developing (Teacher Educator 9).

Another teacher educator noted:

Pesticides have been used in the past to kill weeds, but in fact they also destroyed the insects of pollination, and now pollination must be done by hand (Teacher Educator 2).

Participants also discussed some of the more contentious scientific practices, whose outcomes and impacts are more difficult to gauge. Interviewees mentioned the debate around the positive and negative implications of using genetically modified organisms (GMO) for food in areas of poverty or depravation. One teacher educator pointed out:

The effects of them [GMOs] will only become apparent 20 or 30 years from now, after large populations of people have been consuming these for a long time (Teacher Educator 5).

When questioned about ethical considerations associated with science and scientific developments, teacher educators had a variety of views. Some did not feel ethical considerations were relevant to their area of work. One teacher educator noted:

Any of these new discoveries ... they're value neutral ... it's the value that people put on them then, depending on what uses they've put them to (Teacher Educator 10).

Others noted a real need for ethical and moral elements to be incorporated into science education, saying:

I think everything should be up for discussion. I think in science the very moment that something is put beyond the realm of discussion, it's already a form of censorship (Teacher Educator 9).

Teacher educators spoke of how scientific information can be adapted and presented for public consumption and how mixed or unclear messages can contribute to public distrust of science. For example, one interviewee spoke about clean energy alluding to the negative public opinion pertaining to nuclear energy, and the need to have critical public debate about nuclear energy as a viable substitute for fossil fuels, suggesting that renewable energy is not sufficient or feasible. He spoke about the impact that the media can have on public perception of issues, how "scaremongering" can occur, and how the public can lack scientific knowledge or the awareness necessary to truly engage in these debates. He stated:

I think there needs to be a serious debate about nuclear energy and the Government [is] saying, 'Well, we're not going to have it, therefore we don't need a debate,' which is totally indefensible (Teacher Educator 10).

Another referred to the paucity of scientific literacy among the general public in debating issues relating to science and society. There was also a suggestion that some people do not know how to read scientific information or even trust scientific evidence. This interviewee gave an example of the use of incinerators as a means to dispose of waste, and the public reluctance to this, saying,

I'd say the public have a deep distrust of science a lot of the time. You know, in relation to health issues and stuff like that, I mean the incineration debate is another interesting one. Now people are quite happy to burn plastic in their backyard, smoke cigarettes; but they don't want incineration (Teacher Educator 9). 
In relation to the issue of trust, another teacher educator cautioned how science is communicated to the public, and how commercial interests might be served in how scientific research is reported.

So, as a scientist, my advice is, don't trust scientists ... because we are driven by the need to keep our laboratories funded, and some can be swayed by big industry (Teacher Educator 5).

Related to this, scientific messages that are relayed to the public can be inconsistent and unclear, and research outcomes do not always benefit everyone equally.

And the problem of course is that you get told one thing by one expert, and one by another expert, and which expert do you believe? I worry about the politics behind all these functional foods for example. Funding is given to science that can benefit the health of the Irish population. But the people who need the help aren't able to afford a $€ 3$ [pack of] margarine (Teacher Educator 5).

Teacher educators spoke of the importance of supporting pre-service teachers to develop critical scientific literacy, and the capacity to understand and contribute to scientific debate relating to important socio-scientific issues. They indicated that science education should incorporate discussion and that to deny such debates suppresses challenges to the dominant narrative. Pre-service teachers reiterated the relevance of learning about science and society and teaching this as part of their science subjects, thereby enabling pupils to "open their eyes" to science applications in the real world. In focus groups, they expressed their appreciation for learning about science in society, and applications of science to change the world for the better.

It's important that we teach the social aspect of science... We are not just teaching $a$ subject like biology, we are saying this is what happens in the real world... Its more about life, like pollution or whatever, and the way it affects everybody in the world (Pre-service teacher 8).

It [global awareness and sustainability] opens their [pupils'] eyes a bit as well to see what's going on beyond their own back garden ... So they know that what we do here affects other countries (Pre-service teacher 9).

\subsection{Barriers to Discursive Pedagogies in Science Education Teacher Education}

The nature of science as an academic discipline has a strong bearing on devising approaches for the integration of ESD in academic programs. The hard, vast, technical, cumulative nature of scientific knowledge poses challenges for educators of pre-service teachers. The range of sub-disciplinary areas to be addressed in the Science Education (biological sciences) is one such challenge. Biology-related modules associated with the teacher education program include, microbiology, physiology, biotechnology, biodiversity, genetics and agriculture. The relatively short duration of modules (15 weeks) poses a challenge for packaging the vast scientific knowledge associated with the sub-discipline into manageable and appropriate module units for pre-service teachers. Teacher educators reported a number of barriers to the inclusion of discursive pedagogies in biological science education including volume of content, communication of the fundamentals/key concepts and compartmentalization of knowledge. Interview participants spoke of the sheer magnitude of material that they felt should be included, the "cramming" of information, and the desire to impart to students the essence of the scientific area, providing them with sufficient technical knowledge to grasp key facts, concepts and techniques. In referring to the general nature of the Science Education (biological sciences) program, and the contributions of many lecturers in a variety of disciplines, one teacher educator noted:

It has to be a bit of a 'capture all' and give everybody a taste of everything ... I don't really know how they can get around that, because everyone's going to see their discipline as probably the most important (Teacher Educator 5).

Teacher educators spoke of the importance of communicating the "fundamentals" of the discipline. When speaking about how to structure modules for pre-service teachers, 
participants noted that the process of selection of material focused on providing the basics of the scientific area in sufficient depth as to provide them with an understanding of the key concepts:

It's about getting across the fundamentals, the core ideas while also giving them a feel for the scope of the area, and basic techniques... it's difficult to get the whole subject encapsulated in 12 weeks (Teacher Educator 5).

The same interviewee went on to explain about microbiology:

We're trying to give a little bit on how it impacts on health, food, the environment and the industrial applications, which is the other side of it ... it's a science that touches on a lot of things (Teacher Educator 5).

Based on the overview of modules provided by interviewees, it was clear that modules focused on hard knowledge, providing the key concepts relating to each area of study. From observations in laboratory sessions and lectures, modules offered to pre-service teachers were strongly framed. Lecture observations demonstrated that teaching styles were largely didactic with a focus on transmission of knowledge, rather than providing opportunity for discursive teaching and learning activities. The teacher educator controlled the sequencing and pacing of knowledge, what was to be learned and what was to be examined. While students were given autonomy to carry out their own laboratory work, laboratory sessions are largely structured, and procedures are provided. One interviewee indicated that modules are:

Very general ... that they have to be different from modules that are taught in other programs-let's say a genetics module taught to somebody who is training to be a geneticist versus somebody who is training to be a teacher (Teacher Educator 10).

In focus groups, pre-service teachers noted their frustrations regarding module content, indicating that the depth of material was excessive, or that it did not align closely with school subject curricula. A pre-service teacher noted:

Some of what we cover is so detailed, it goes way above what we'll ever teach in schools. (Preservice teacher 2).

In interviews, teacher educators noted a number of challenges with regards pre-service teachers' learning and engagement with modules. They spoke of students' "compartmentalization" of knowledge. This was noted in relation to their capacity to transfer knowledge from the lecture to the laboratory setting, and from one module to another. One teacher educator noted:

Sometimes, we have to cram information into a format that doesn't let them see what it actually means, and the significance of it. Now, we may be hoping for a lot in first years ... actually, because even with second years, what I'm seeing here is that they're not making the links between the different components (Teacher Educator 5).

The same teacher educator described his surprise, when he asked pre-service teachers to recall a previous module where they created microbial cultures using everyday materials. He explained that they had grown bacterial cultures using their own skin and hair samples but failed to be able to recount this. He explained:

The labs were designed to show them what [bacteria] is actually on their own skin and hair ... it blows my mind that they don't remember this, because they seem to enjoy the labs associated with it (Teacher Educator 5).

Findings also highlighted pre-service teachers' learning habits. Tutors who supervised laboratory sessions spoke of students seeking to provide "correct answers" in laboratory sessions and reports, in order to meet the course requirements and gain marks, rather than engaging in genuine inquiry to support development of scientific literacy. Pre-service teachers indicated that their learning was strategic, and at times exam focused, rather than nurturing their professional development. They also indicated that they prioritised assignments and tasks that carried more weight in assessment. One pre-service teacher commented: 
We're always busy, we have lectures and labs as well as tutorials and then we've teaching practice too and all the assignments on top of that. There just isn't time to think, and you're not going to spend time on something that doesn't have marks (Pre-service teacher 11).

\subsection{Sustainability in Existing Science Education Modules}

Observations of lectures in some modules noted a strong alignment with sustainable development themes. 'Soil Science' lectures explored links between climate change and land use and the potential for carbon sequestration. In the 'Agriculture' modules, students were introduced to themes relating to sustainability, including organic versus intensive farming and the growing and use of biofuels. Interviews with faculty members highlighted that the existing modules (including General Biology, Soil Science, Agriculture 1, Diversity of Organisms and General Microbiology) reference a range of sustainability themes. Interviewees also referenced sustainability links in other modules, including content that addresses biodiversity, ecology, water quality, food security, health and energy. However, some lecturers noted that sustainable development was not relevant to the delivery of their particular science education (biological sciences) module. For example, the biochemistry lecturer highlighted that:

A large portion of what I teach is chemical structure, the nearest I get to a whole organism is looking at an organ or muscle or a nerve ... and so it's really quite remote really from saying to a student, 'Well we need to develop a new process for recycling plastic,' (Teacher Educator 4).

When asked if discussions and conversations on sustainability topics (such as nuclear energy versus renewable energy) took place as part of pedagogy modules, one teacher educator commented:

I would hold up my hands and say that it's not being done ... I think the big problem there is that there is a focus obviously on the scientific skills and actually being able to do the experiments (Teacher Educator 2).

During focus groups, pre-service teachers generally felt the inclusion of ESD in teaching to be a positive endeavour. One student commented:

The world is becoming a smaller place and you know going back to the concept of like global village, I think it would be important from that aspect that pupils get to know like other countries, cultures, what's going on for people (Pre-service teacher 1).

Some reiterated the importance of it being core to the curriculum and not something that teachers teach because they themselves see it as important. One student noted:

I would say generally it should be in some way fitted into school life ... because it's very hard for any one teacher [to] take it on for themselves to do it. (Pre-service teacher 9).

Some were unsure about the relevance of ESD to science, indicating that it pertains more to humanities subjects than the natural sciences, saying:

This [ESD] sounds very airy-fairy, but I think it would be good for their own personal moral education ... take their eyes off themselves and see other issues; then their own smaller issues won't seem to so big in their eyes. (Pre-service teacher 6).

Others noted the pressures of the formal system and the need for the curriculum and assessment to be reflective of ESD for it to be taken seriously by pupils and parents, commenting:

I thought it would be more for the Junior Cycle [lower second level education], because when you are doing your Leaving Cert [upper second level education] you just want to know what's going to be in the exam. It's all about points. But for Junior Cert [state examination], it's not as important and, like first and second year, you have a wee bit of extra time to maybe do some of that interesting stuff (Pre-service teacher 9).

They also spoke about the fear that ESD will result in them having to teach additional material. One student noted: 
It's very hard to link it to science... and also do all the work we're trying to do at the moment (Pre-service teacher 4).

Another noted their concern that deviating from the core subject specification might be difficult:

You'd get a few minutes for it every so often like or half an hour, but you are under pressure from the pupils and the parents to help them get the best results they can. Sometimes, that takes over, assessment takes over (Pre-service teacher 12).

However, others disagreed with this sentiment, stating:

I didn't even realise I was doing it ... In my second year school placement class, we were doing ecology, talking about resources we use, etc. I got all of them to design a house that was environmentally friendly ... they had solar panels, using water in the drainpipes to water the flowers, cut down on the oil ... all stuff that would help the environment (Pre-service teacher 8).

Not really, though, [because] we have a lot of environmental stuff ... you could at least bring that in (Pre-service teacher 10).

When asked about opportunities for ESD in their teaching, pre-service teachers recognised a range of examples where they could facilitate discussions. Specifically, they mentioned global warming, genetic engineering, renewable energy sources such as solar and biofuels, pollution, nuclear energy, recycling, DNA profiling, diversification of farming (first and third world), deforestation and preservation of ecological diversity. When asked where this content is currently reflected in their program, they mentioned modules relating to agriculture, pollution biology, ecology and soil science. However, it is noteworthy that many of the references to sustainability pointed to hard and technical scientific knowledge, rather than to social, economic or cultural considerations.

Some teacher educators suggested the introduction of a Science in Society module in the Science Education (biological sciences) program to allow for a critical examination of the role of science in development. When considering science and society, one interviewee suggested:

I feel it has been neglected to some degree... While individual lecturers and contributors might raise awareness [of it], there isn't a module which looks at an end view and one where science is looked at in terms of its contribution to society (Teacher Educator 9).

\section{Discussion}

This study set out to explore the nature of science as an academic discipline and its capacity for the integration of ESD. An ethnographic-informed research design was adopted to explore the following research question: how does the relationship between science and society, in the context of the Science Education (biological sciences) program, support and/or challenge the integration of ESD? Findings point to a strong link between science and society in science education, and the need for learners to develop critical scientific literacy that enables them to meaningfully navigate multiple perspectives presented in media and public debates. Results highlighted some challenges to adopting discursive pedagogical approaches in the science education program. Finally, while sustainability themes permeated some modules in the program, the emphasis was on imparting hard, technical knowledge rather than allowing for the critical, discursive exploration of issues. These results shall be discussed from the perspective of building critical scientific literacy through engagement with SSI, standalone modules, and integration of discursive-based pedagogical approaches.

\section{Building Critical Scientific Literacy}

While findings from the current study point to the strong links between science and society, if students are to build critical scientific literacy, then they must develop an awareness of the influencing factors associated with scientific messages. Critical scientific literacy implies that they are capable of identifying reliable data and sources of information, recognizing biases and contradictions, generating primary data, being solutions-focused and 
futures-orientated, and constructing arguments that are evidence-based. For example, fake news and misleading headlines during the COVID crisis resulted in confusion and anxiety among the public leading to the Health Service Executive (HSE) of Ireland [127] publishing guidelines on dealing with misinformation during the pandemic. Scientific learning about the production of vaccines, disease control, as well as the process of identifying evidence-based information, and considering human behaviour and choices in such situations can be incorporated into teaching about science and society. While results from this study support the link between science and society including the permeation of sustainability themes in some modules, the emphasis was often on technical knowledge ('scientific fundamentals/concepts') rather than providing time and space to explore the human and social implications. This finding is consistent with Eilks [111], who notes that in many cases in tertiary education, science teaching tends to limit the focus of sustainabilityrelated issues to the scientific background and/or subject matter content, rather than extending into discursive consideration of other factors. Previous research promotes the importance of social issues in scientific literacy [45-48,91], yet some raise concerns that the issues are overly complex for the classroom and that time should be devoted to teaching and learning important fundamental scientific concepts and practices instead [128]. The prevalence of sustainability-related themes in existing modules in this study bodes well for the inclusion of ESD, yet the focus on hard or technical scientific knowledge remains a concern. It may be important to consider how social and economic perspectives on global issues can be explored, while remaining true to the nature and integrity of science as an academic discipline as it is packaged in HEIs. Many sustainability issues require multidimensional perspectives $[92,94]$ and one needs to acknowledge the strong classification of science [129] to generate and facilitate opportunities that promote the skills-based, discursive and transformative nature of ESD $[95,130,131]$. Without adequate inclusion of these learning experiences, any educational provision might be considered "education about sustainability", rather than "education for sustainability" [132]. Thus, while learners may acquire new knowledge, they are less likely to experience value changes or lasting behavioural change [12].

Arguably the inclusion of socio-scientific issues (SSI) in science education offers an educational framework drawing upon areas of study, including socio-moral discourse and ethics that may support the development of critical scientific literacy $[39,54,55,60,133]$. SSI draw upon both social and scientific factors to address real-world problems and can often be controversial, requiring consideration of personal, ethical, and moral values $[39,55,60,90,134]$. Zeidler and Sadler suggest that this influences how the learners see and perceive knowledge, and facilitates them to connect with their own values, ethics, and morals [54]. Pertinent issues in biological science education may reflect the Sustainable Development Goals and include responses to the COVID-19 global pandemic, the climate change crisis, and water quality preservation. Cinici advocates that "the more understanding about the nature of scientific knowledge and scientific enterprise students have, the more they develop scientifically balanced risk perception about controversial scientific issues" (p. 1862, [57]). The Irish lower second level science curriculum is structured to support students to probe socio-scientific issues by asking relevant questions and consider more deeply how they reflect upon the problem [45]. This in turn must be translated into pre-service teacher education so that graduates are equipped with the pedagogical skills to meet the requirements of lower second level science. It is important that pre-service teachers are supported in their transition from understanding the social aspects of science, to becoming designers of learning activities that promote social aspects of science [58]. Gul and Akcay support the use of a critical thinking framework for addressing SSI in pre-service teacher education [135]. During the decisionmaking process, personal values, morals, ethics and social concerns are taken into account in an explicit or implicit way [63,136-138]. This contributes to the formation of virtue in the learner and can challenge the assumptions of dominant knowledge claims, to support traits such as empathy, care, responsibility, and willingness to take action $[39,48,60]$. Collaborative opportunities for constructing and communicating evidence-based viewpoints relating to 
SSI are important for ESD and for scientific competence more generally [55,139-141]. ESD focuses on real-world development problems that require informed and culturally appropriate solutions that bring about change in behaviour, which can be supported through engagement with SSI.

Alternately, the inclusion of a standalone Science in Society module could offer opportunities to explore SSI and ESD. This offering may enable learners to develop their understanding of the effects of science on society and the environment, and also consider how scientific results are communicated to and perceived by the public [142]. Introducing a dedicated Science in Society module as a mandatory component of the Science Education (biological sciences) program could be beneficial in exploring the social contributions and implications of science in a manner that is consistent with ESD. Such a module could provide opportunities to facilitate discussion on science as it pertains to local and global issues, challenges and demands (for example the NOS, the impacts of science on social outcomes, ethical issues in science, public understanding of science and science in the context of the environment, health, the modern economy and the implications for public policy formation of "knowledge-based societies"). Students might be supported in asking how political decisions are made, how science can inform decisions, how science can support development in a way that is sustainable and safe, and what ecological, social and economic factors should be considered when making decisions. However, the idea of a standalone module contradicts, in some ways, the Strengths Model, which advocates that each subject and disciplinary area embed ideas of sustainable development into their teaching. Such an approach places the responsibility on individual educators to teach for sustainability $[9,143]$. Equally, the inclusion of a Science in Society module would not preclude the necessity for module leaders to include sustainability in their respective modules.

However, in order to embrace a focus on developing students' critical science literacy, educators must integrate a focus on discursive pedagogies acknowledging the barriers that are eminent within the discipline. Teacher educators in this study noted the challenges they experienced in providing opportunities for dialogue, discussion, and debate in the learning spaces associated with the Science Education (biological sciences) program. DeBoer argues that teaching for scientific literacy is more successful when the learner is not expected to master significant bodies of content and that placing an emphasis on standards-based, knowledge focused testing can inhibit the autonomy and creativity of science teachers [38]. Similarly, DiCarlo states that educators of science should abandon the mistaken notion that unless they "cover the content" they have not achieved their goal and recognise the importance of motivating and inspiring their students to continue to learn [144]. Approaches to teaching science that focus on transmission of knowledge rather than development of scientific skills lead to students committing a great deal of knowledge to memory, without having any grounding for that knowledge [145]. The emphasis on content and transmission of knowledge identified in the findings of this study has implications for the integration of ESD into the Science Education (biological sciences) program. ESD requires action-based, interactive and discursive pedagogies that allow the learner space and time to reflect upon issues from a variety of perspectives, acquire appropriate knowledge, explore issues from within local and global contexts and derive appropriate courses of action to address the issue. Discourse-based pedagogies are emphasised as a means for students to practice negotiations of SSI and explore diverse viewpoints on the issues [67]. SSIs support the learner to develop the skills necessary to actively participate in classroom debates, thereby enhancing their capacity to take part in societal decision-making processes [146]. Such approaches might be supported by educational tools such as role-playing, conducting research on how science is represented in the media, or discussing the role science plays (or should play) in advertising [147], simulations, group discussions, and debate [148]. The more engaged students are at generating claims or arguments relating to SSI, the more engaged they become with related issues [149,150], as they, re-evaluate their prior knowledge, and re-conceptualise their understanding of the subject matter through personal experiences and social discourse [55]. 


\section{Conclusions}

Science education has an important role to play in preparing learners to engage with and respond to the key global challenges of our time. Science as an academic discipline provides unique opportunities to explore sustainability given the nature of the discipline, the knowledge it reflects, and the inquiry nature of science pedagogy. The inextricable links between science and society evident in this research provide potential to develop critical scientific literacy where students come to understand and contribute to scientific debate relating to important socio-scientific issues. Such approaches are consistent with literature on science education and scientific literacy, but also resonate with the fundamental principles and pedagogies of ESD. While many scientific areas of study align with the principles of sustainability, there are challenges to integrating ESD. The hard, expansive, and cumulative nature of scientific knowledge contributes to pedagogical approaches that are didactic, content driven and strongly framed. This results in learning environments that prioritise content and procedural scientific literacy at the expense of epistemic scientific literacy. Erduran argues that the science education community must design heuristics that include authentic representations of the complexity of the scientific process approximating the cognitive, epistemic, and social-institutional dimensions of science [151]. Barriers to student learning noted in the study were curriculum overload, pre-service teachers' compartmentalization of knowledge, and their strategic approaches to learning that are exam oriented rather than nurturing their professional development. These challenges must be addressed in the program in order to provide appropriate learning spaces to engage in issues central to ESD. Reflective of the educational paradigm shift that is central to ESD, the authors suggest a shift from content-driven modules to scientific inquiry based learning and discursive pedagogies that support the development of critical scientific literacy. Equally, this could be achieved through the development of a collaboratively constructed Science in Society module to augment offerings in individual modules. This module would draw on key learning outcomes from existing science-based modules and provide a mechanism to actively explore topics such as ethics in science, public understandings of science, and the nature of science, while also linking with the local environment and community.

Author Contributions: Study conception and design: D.H. and J.O. Acquisition of data: D.H. Analysis and interpretation of data: D.H. and J.O. Manuscript preparation: D.H. and J.O. Critical revision: D.H. and J.O. All authors have read and agreed to the published version of the manuscript.

Funding: This research received no external funding.

Institutional Review Board Statement: The study was conducted according to the guidelines for research with human subjects and approved by the Institutional Review Board (or Ethics Committee) of the University of Limerick (Ethics Approval Number: COE_20120506).

Informed Consent Statement: Informed consent was obtained from all subjects involved in the study.

Data Availability Statement: All data, or codes generated or used during the study are available by request.

Conflicts of Interest: The authors declare no conflict of interest.

\section{References}

1. UN, United Nations. Report of the United Nations Conference on the Human Environment, Stockholm, 5-16 June 1972; United Nations: New York, NY, USA, 1972.

2. UNESCO. Final Report of the Intergovernmental Conference on Environmental Education; UNESCO: Paris, France, 1978.

3. WCED. Our Common Future-The World Commission on Environment and Development; Oxford University Press: Oxford, UK, 1987.

4. UNESCO. Education for Sustainability_From Rio to Johannesburg: Lessons Learnt from a Decade of Commitment; UNESCO: Paris, France, 2002.

5. Long, G. The idea of universality in the sustainable development goals. Ethics Int. Aff. 2015, 29, 203-222. [CrossRef]

6. UNEP. Universality in the Post 2015 Sustainable Development Agenda, Note \#9. 2015. Available online: http://www.ohchr.org/ Documents/Issues/MDGs/Post2015/OHCHR_UNEP.pdf (accessed on 22 June 2021). 
7. UN, United Nations. Transforming Our World: The 2030 Agenda for Sustainable Development; United Nations: New York, NY, USA, 2015. Available online: https://sustainabledevelopment.un.org/post2015/transformingourworld/publication (accessed on 22 June 2021).

8. $\quad$ Freire, P. Pedagogy of the Oppressed; Herder and Herder: New York, NY, USA, 1972.

9. Hopkins, C.; McKeown, R. The International Network. Guidelines and Recommendation for Reorienting Teacher Education to Address Sustainability. Education for Sustainable Development in Action Technical Paper No. 2; UNESCO: Paris, France, 2005. Available online: http:/ / unesdoc.unesco.org/images/0014/001433/143370E.pdf (accessed on 10 April 2020).

10. Becher, T. Academic Tribes and Territories: Intellectual Inquiry and the Cultures of Disciplines; SRHE/OUP: Milton Keynes, UK, 1989.

11. Becher, T.; Trowler, P.R. Academic Tribes and Territories: Intellectual Inquiry and the Culture of Disciplines, 2nd ed.; Open University Press: Buckingham, UK, 2001.

12. Becher, T. The significance of disciplinary differences. Stud. High. Educ. 1994, 19, 151-161. [CrossRef]

13. Brush, S.G. The History of Modern Science: A Guide to the Second Scientific Revolution 1800-1950; Iowa State University Press: Ames, IA, USA, 1989.

14. Ziman, J. Real Science: What It Is and What It Means; Cambridge University Press: Cambridge, UK, 2004.

15. Ratcliffe, M.; Grace, M. Science Education for Citizenship_Teaching Socio-Scientific Issues; Open University Press: Maidenhead, UK, 2003.

16. Weinberg, S. To Explain the World: The Discovery of Modern Science; Harper Perennial: London, UK, 2016.

17. Okasha, S. Philosophy of Science: A Very Short Introduction; Oxford University Press: Oxford, UK, 2002.

18. Bell, R.L. Teaching the Nature of Science: Three Critical Questions. Best Practices in Science Education Monograph; National Geographic School Publishing: Carmel, CA, USA, 2009.

19. McCain, K. Explanation and the nature of scientific knowledge. Sci. Educ. 2015, 24, 827-854. [CrossRef]

20. Reiss, J.; Sprenger, J. Scientific objectivity. In The Stanford Encyclopedia of Philosophy; (Winter 2017 Edition); Zalta, E.N., Ed.; 2017. Available online: https:/ / plato.stanford.edu/archives/win2017/entries/scientific-objectivity (accessed on 30 June 2021).

21. Mannan, M.D. Science and subjectivity: Understanding objectivity of scientific knowledge. Philos. Prog. 2016, LIX-LX, 1607-2278. [CrossRef]

22. Kelly, R.; Erduran, S. Understanding aims and values of science: Developments in the junior cycle specifications on nature of science and pre-service science teachers' views in Ireland. Ir. Educ. Stud. 2018, 38, 43-70. [CrossRef]

23. Anthony, H.D. Scientific Literature and the Classification of the Sciences. Bull. Br. Soc. Hist. Sci. 1958, 2, 97-98. [CrossRef]

24. Ziman, J. Knowing Everything about Nothing: Specialization and Change in Research Careers; Cambridge University Press: Cambridge, UK, 1987.

25. Ziman, J. An Introduction to Science Studies: The Philosophical and Social Aspects of Science and Technology; Cambridge University Press: Cambridge, UK, 1984.

26. Schneider, A.M. Four stages of a scientific discipline; four types of scientist. Trends Biochem. Sci. 2009, 34, 217-223. [CrossRef]

27. Kuhn, T.S. The Structure of Scientific Revolutions, 2nd ed.; University of Chicago Press: Chicago, IL, USA, 1970.

28. Biglan, A. The characteristics of subject matter in different scientific areas. J. Appl. Psychol. 1973, 57, 195-203. [CrossRef]

29. Valiela, I. Doing Science-Design, Analysis, and Communication of Scientific Research, 2nd ed.; Oxford University Press: New York, NY, USA, 2009.

30. Chadwick, R.; McLoughlin, E.; Finlayson, O. Assessment of scientific literacy through socioscientific issues with secondary school science students. In Proceedings of the European Science Education Research Association (ESERA) Conference, Dublin City University, Dublin, Ireland, 21-25 August 2017.

31. Laugksch, R.C. Scientific literacy: A conceptual overview. Sci. Educ. 2000, 84, 71-94. [CrossRef]

32. Roberts, D.A. Scientific literacy/science literacy. In Handbook of Research in Science Education; Abell, S.K., Lederman, N.G., Eds.; Routledge: London, UK, 2007; pp. 729-780.

33. Millar, R. Taking scientific literacy seriously as a curriculum aim. Asia-Pac. Forum Sci. Learn. Teach. 2008, 9, 1-18.

34. OECD, Organisation for Economic Co-operation and Development. PISA 2015 Assessment and Analytical Framework Science, Reading, Mathematic, Financial Literacy and Collaborative Problem Solving; OECD: Paris, France, 2016.

35. OECD, Organisation for Economic Co-operation and Development. PISA 2018 Assessment and Analytical Framework; OECD: Paris, France, 2018. Available online: https: / / www.oecd-ilibrary.org/docserver/b25efab8-en.pdf?expires=1620814572\&id=id\& accname=guest\&checksum=9CB0BE9DBF05EF1BCCB405B68BD71518 (accessed on 30 June 2021).

36. Bybee, R.W. Towards an understanding of scientific literacy. In Scientific Literacy. An International Symposium; Gräber, W., Bolte, C., Eds.; Institut für die Pädagogik der Naturwissenschaften (IPN): Kiel, Germany, 1997.

37. Neumann, I. Beyond Physics Content Knowledge-Modeling Competence Regarding Nature of Scientific Inquiry and Nature of Scientific Knowledge; Logos Verlag Berlin: Berlin, Germany, 2011.

38. DeBoer, G.E. Scientific literacy: Another look at its historical and contemporary meaning and its relationship to science education reform. J. Res. Sci. Teach. 2000, 37, 582-601. [CrossRef]

39. Zeidler, D.L.; Sadler, T.D.; Simmons, M.L.; Howes, E.V. Beyond STS: Research-based framework for socioscientific issues education. Sci. Educ. 2005, 89, 357-377. [CrossRef]

40. Holbrook, J. Introduction to the special issue of science education international devoted to PARSEL. Sci. Educ. Int. 2008, 19, 257-266. 
41. Roth, W.M.; Lee, S. Science education as/for participation in the community. Sci. Educ. 2004, 88, 263-291. [CrossRef]

42. Lederman, N.G.; Antink, A.; Bartos, S. Nature of science, scientific inquiry, and socio-scientific issues arising from genetics: A pathway to developing a scientifically literate citizenry. Sci. Educ. 2014, 23, 285-302. [CrossRef]

43. Holbrook, J.; Rannikmae, M. The Nature of science education for enhancing scientific literacy. Int. J. Sci. Educ. 2007, 29, 1347-1362. [CrossRef]

44. Liu, S.Y.; Lin, C.S.; Tsai, C.C. College students' scientific epistemological views and thinking patterns in socioscientific decision making. Sci. Educ. 2011, 95, 497-517. [CrossRef]

45. NCCA, National Council for Curriculum and Assessment. Jr. Cycle Sci. 2019. Available online: https:/ / www.curriculumonline. ie/Junior-cycle/Junior-Cycle-Subjects/Science/ (accessed on 10 March 2020).

46. Lederman, N.G.; Lederman, J.S.; Antink, A. Nature of science and scientific inquiry as contexts for the learning of science and achievement of scientific literacy. Int. J. Educ. Math. Sci. Technol. 2013, 1, 138-147.

47. Sadler, T.D. Situating socio-scientific issues in classrooms as a means of achieving goals of science education. In Socio-Scientific Issues in the Classroom: Teaching, Learning and Research; Sadler, T.D., Ed.; Springer: Dordrecht, The Netherlands, 2011; pp. 1-10.

48. Zeidler, D.L. Socioscientific issues as a curriculum emphasis: Theory, research, and practice. In Handbook of Research on Science Education; Lederman, N.G., Abell, S.K., Eds.; Routledge: London, UK, 2014; Volume II, pp. 697-726.

49. OECD. Organisation for Economic Co-operation and Development. Knowledge and Skills for Life. First Results from the OECD Programme for International Student Assessment (PISA) 2000; Organisation for Economic Co-operation and Development: Paris, France, 2001. Available online: http:/ /www1.oecd.org/publications/e-book/9601141e.pdf (accessed on 22 December 2015).

50. Osborne, J.; Dillon, J. Science Education in Europe: Critical Reflections; The Nuffield Foundation: London, UK, 2008.

51. Ziman, J. Teaching and Learning about Science and Society; Cambridge University Press: Cambridge, UK, 1980.

52. Kumar, D.D.; Berlin, D.F. A study of STS curriculum implementation in the United States. Sci. Educ. 1996, 5, 12-19.

53. Mansour, N. Science-Technology-Society (STS): A new paradigm in science education. Bull. Sci. Technol. Soc. 2009, 29, 287-297. [CrossRef]

54. Zeidler, D.L.; Sadler, T.D. Social and ethical issues in science education: A prelude to action. Sci. Educ. 2008, 17, 799-803. [CrossRef]

55. Zeidler, D.L.; Nichols, B.H. Socioscientific issues: Theory and practice. J. Elem. Sci. Teach. Educ. 2009, 21, 49-58. [CrossRef]

56. Abd-El-Khalick, F. Socioscientific issues in pre-college science classrooms: The primacy of learners' epistemological orientations and views of nature of science. In The Role of Moral Reasoning in Socioscientific Issues and Discourse in Science Education; Zeidler, D.L., Ed.; Kluwer: Dordrecht, The Netherlands, 2003; pp. 41-61.

57. Cinici, A. Balancing the pros and cons of GMOs: Socio-scientific argumentation in pre-service teacher education. Int. J. Sci. Educ. 2016, 38, 1841-1866. [CrossRef]

58. Evagorou, M.; Puig Mauriz, B. Engaging elementary school pre-service teachers in modeling a socioscientific issue as a way to help them appreciate the social aspects of science. Int. J. Educ. Math. Sci. Technol. 2017, 5, 113-123. [CrossRef]

59. Sadler, T.D. Situated learning in science education: Socio-scientific issues as contexts for practice. Stud. Sci. Educ. 2009, 45, 1-42. [CrossRef]

60. Zeidler, D.L.; Keefer, M. The role of moral reasoning and the status of socioscientific issues in science education: Philosophical, psychological, and pedagogical considerations. In The Role of Moral Reasoning and Discourse on Socioscientific Issues in Science Education; Zeidler, D.L., Ed.; Science \& Technology Education Library; Kluwer: Dordrecht, The Netherlands, 2003; Volume 19, pp. 7-38.

61. Sadler, T.D.; Zeidler, D.L. The morality of socio-scientific issues: Construal and resolution of genetic engineering dilemmas. Sci. Educ. 2004, 88, 4-27. [CrossRef]

62. Gresch, H.; Hasselhorn, M.; Bögeholz, S. Training in decision-making strategies: An approach to enhance students' competence to deal with socio-scientific issues. Int. J. Sci. Educ. 2013, 35, 2587-2607. [CrossRef]

63. Oulton, C.; Dillon, J.; Grace, M.M. Reconceptualizing the teaching of controversial issues. Int. J. Sci. Educ. 2004, 26, 411-423. [CrossRef]

64. Christenson, N.; Chang-Rundgren, S.N. A framework for teachers' assessment of socio-scientific argumentation: An example using the GMO issue. J. Biol. Educ. 2015, 49, 204-212. [CrossRef]

65. Dawson, V.M.; Venville, G. Teaching strategies for developing students' argumentation skills about socioscientific issues in high school genetics. Res. Sci. Educ. 2010, 40, 133-148. [CrossRef]

66. Foong, C.C.; Daniel, E.G.S. Students' argumentation skills across two socio-scientific issues in a Confucian classroom: Is transfer possible? Int. J. Sci. Educ. 2013, 35, 2331-2355. [CrossRef]

67. Bossér, U. Exploring the complexities of integrating socioscientific issues in science teaching. Doctoral Dissertation, Linnaeus University, Växjö, Sweden, 2018.

68. Van Eijck, M.; Roth, W.M. Improving Science education for sustainable development. PLoS Biol. 2007, 5, e306. [CrossRef] [PubMed]

69. Wilke, R.R.; Straits, W.J. The effects of discovery learning in a lower-division biology course. Adv. Physiol. Educ. 2001, 25, 62-69. [CrossRef] [PubMed]

70. Freeman, S.; Eddy, S.L.; McDonough, M.; Smith, M.K.; Okoroafor, N.; Jordt, H.; Wenderoth, M.P. Active learning boosts performance in STEM courses. Proc. Natl. Acad. Sci. USA 2014, 111, 8410-8415. [CrossRef] [PubMed] 
71. Michael, J. Where's the evidence that active learning works? Adv. Physiol. Educ. 2006, 30, 159-167. [CrossRef]

72. Erduran, S.; Dagher, Z. Reconceptualizing the Nature of Science for Science Education: Scientific Knowledge, Practices and Other Family Categories; Springer: Dordrecht, The Netherlands, 2014.

73. O'Grady, A.; Simmie, G.M.; Kennedy, T. Why change to active learning? Pre-service and in-service science teachers' perceptions. Eur. J. Teach. Educ. 2014, 37, 35-50. [CrossRef]

74. NRC, National Research Council. Inquiry and the National Science Education Standards: A Guide for Teaching and Learning; National Academy Press: Washington, DC, USA, 2000.

75. Lunetta, V.N.; Hofstein, A.; Clough, M.P. Learning and teaching in the school science laboratory: An analysis of research, theory and practice. In International Handbook of Science Education; Abell, S.K., Lederman, N.G., Eds.; Lawrence Erlbaum: Mahwah, NJ USA, 2007; pp. 393-441.

76. Lederman, N.G.; Lederman, J. Nature of scientific knowledge and scientific inquiry: Building instructional capacity through professional development. In Second International Handbook of Science Education; Fraser, B.J., Tobin, K., McRobbie, C.J., Eds.; Springer: Dordrecht, The Netherlands, 2012; pp. 335-359.

77. Asay, L.D.; Orgill, M. Analysis of essential features of inquiry found in articles published in the Science Teacher, 1998-2007. J. Sci. Teach. Educ. 2010, 21, 57-79. [CrossRef]

78. Gallagher, S.A.; Stepien, W.J.; Sher, B.T.; Workman, D. Implementing problem-based learning in science classrooms. Sch. Sci. Math. 1995, 95, 136-146. [CrossRef]

79. Kendler, B.; Grove, P. Problem-based learning in the biology curriculum. Am. Biol. Teach. 2004, 666, 348-354. [CrossRef]

80. Akçay, B. Problem-based learning in science education. J. Turk. Sci. Educ. 2009, 6, 26-36.

81. Gallagher, S. The role of problem-based learning in developing creative expertise. Asia Pac. Educ. Rev. 2015, 16, 225-235. [CrossRef]

82. Driver, R.; Newton, P.; Osborne, J. Establishing the norms of scientific argument in classrooms. Sci. Educ. 2000, 84, 287-313. [CrossRef]

83. Jiménez-Aleixandre, M.P.; Erduran, S. Argumentation in science education: An overview. In Argumentation in Science Education: Perspectives from Classroom-Based Research; Erduran, S., Jiménez-Aleixandre, M.P., Eds.; Springer: Dordre, The Netherland, 2007; pp. 3-27.

84. Berland, L.K.; Reiser, J. Making sense of argumentation and explanation. Sci. Educ. 2009, 39, 26-55. [CrossRef]

85. Bricker, L.; Bell, P. Conceptualizations of argumentation from science studies and the learning sciences and their implications for the practices of science education. Sci. Educ. 2008, 92, 473-498. [CrossRef]

86. Simon, S.; Erduran, S.; Osborne, J. Learning to teach argumentation: Research and development in the science classroom. Int. J. Sci. Educ. 2006, 28, 235-260. [CrossRef]

87. Cavagnetto, A.R. Argument to foster scientific literacy: A review of argument interventions in K-12 science contexts. Rev. Educ. Res. 2010, 80, 336-371. [CrossRef]

88. Osborne, J.; Erduran, S.; Simon, S. Enhancing the quality of argumentation in school science. J. Res. Sci. Educ. 2004, 41, 994-1020. [CrossRef]

89. Jonassen, D.; Kim, B. Arguing to learn and learning to argue: Design justifications and guidelines. Educ. Technol. Res. Dev. 2010, 58, 439-457. [CrossRef]

90. Khishfe, R.; Alshaya, F.S.; BouJaoude, S.; Mansour, N.; Alrudiyan, K.I. Students' understandings of nature of science and their arguments in the context of four socio-scientific issues. Int. J. Sci. Educ. 2017, 39, 299-334. [CrossRef]

91. Vesterinen, V.M.; Tolppanen, S.; Aksela, M. Toward citizenship science education: What students do to make the world a better place? Int. J. Sci. Educ. 2016, 38, 30-50. [CrossRef]

92. Leicht, A.; Heiss, J.; Byun, W. Issues and Trends in Education for Sustainable Development, Education on the Move; UNESCO Publishing: Paris, France, 2018. Available online: http:/ / unesdoc.unesco.org/images/0026/002614/261445e.pdf (accessed on 30 March 2020).

93. UNESCO. Education 2030. Incheon Declaration and Framework for Action. Towards Inclusive and Equitable Quality Education and Lifelong Learning for All; UNESCO: Paris, France, 2016. Available online: www.uis.unesco.org/Education/Documents/incheonframework-for-action-en.pdf (accessed on 17 May 2019).

94. UNESCO. Framework for the UN DESD International Implementation Scheme; UNESCO: Paris, France, 2006.

95. UNESCO. United Nations Decade of Education for Sustainable Development (2005-2014): International Implementation Scheme; UNESCO: Paris, France, 2005.

96. UNESCO. Global Citizenship Education: Preparing Learners for the Challenges of the 21st Century; UNESCO: Paris, France, 2014.

97. O'Flaherty, J.; Liddy, M. The impact of development education and education for sustainable development interventions: A synthesis of the research. Environ. Educ. Res. 2018, 24, 1-19. [CrossRef]

98. UNECE. UNECE Strategy for Education for Sustainable Development. In Proceedings of the High-Level Meeting, Vilnius, Lithuania, 17-18 March 2005. Available online: https:/ /www.unece.org/fileadmin/DAM/env/documents/2005/cep/ac.13/cep. ac.13.2005.3.rev.1.e.pdf (accessed on 20 June 2021).

99. United Nations General Assembly. United Nations Millennium Declaration, Resolution Adopted by the General Assembly; A/RES/55/2; 2002. Available online: https://www.refworld.org/docid/3b00f4ea3.html (accessed on 6 September 2019).

100. McCormack, O.; O'Flaherty, J. Pre-service teacher's views and attitudes towards integrating development education active learning methodologies into their teaching. Teach. Teach. Educ. 2010, 26, 1332-1339. [CrossRef] 
101. Wiek, A.; Withycombe, L.; Redman, C.L. Key competencies in sustainability: A reference framework for academic program development. Sustain. Sci. 2011, 6, 203-218. [CrossRef]

102. Wiek, A.; Bernstein, M.J.; Foley, R.W.; Cohen, M.; Forrest, N.; Kuzdas, C.; Kay, B.; Withycombe Keeler, L. Operationalising competencies in higher education for sustainable development. In Routledge Handbook of Higher Education for Sustainable Development; Barth, M., Michelsen, G., Rieckmann, M., Thomas, I., Eds.; Routledge: London, UK, 2016; pp. 241-260.

103. UNESCO. Education for Sustainable Development Goals: Learning Objectives. Education 2030; UNESCO: Paris, France, 2017.

104. Hogan, D.; Tormey, R. A perspective on the relationship between development education and education for sustainable development. Policy Pract. A Dev. Educ. Rev. 2008, 6, 5-17.

105. Barth, M. Implementing Sustainability in Higher Education-Learning in an Age of Transformation; Routledge: London, UK, 2015.

106. Sterling, S. Sustainable Education: Re-Visioning Learning and Change; Green Books: Totnes, UK, 2001.

107. Rest, A. From "environmental education" to "education for sustainable development"-The shift of a paradigm. Environ. Policy Law 2002, 32, 79-85.

108. Wals, A.E.J.; Jickling, B. "Sustainability" in higher education: From doublethink and newspeak to critical thinking and meaningful learning. Int. J. Sustain. High. Educ. 2002, 3, 221-232. [CrossRef]

109. Wals, A.E.J. Learning Our Way to Sustainability. J. Educ. Sustain. Dev. 2011, 5, 177-186. [CrossRef]

110. Sterling, S. Higher Education, sustainability and the role of systemic learning. In Higher Education and the Challenge of Sustainability: Problematics, Promise and Practice; Corcoran, P.B., Wals, A.E.J., Eds.; Springer: Dordrecht, The Netherlands, $2004 ;$ pp. 47-70.

111. Eilks, I. Science education and education for sustainable development-Justifications, models, practices and perspectives. Eurasia J. Math. Sci. Technol. Educ. 2015, 11, 349-358. [CrossRef]

112. Burmeister, M.; Rauch, F.; Eilks, I. Education for sustainable development (ESD) and chemistry education. Chem. Educ. Res. Pract. 2012, 13, 59-68. [CrossRef]

113. Hammersley, M.; Atkinson, P. Ethnography, Principles in Practice, 3rd ed.; Routledge: London, UK, 2007.

114. Reeves, S.; Kuper, A.; Hodges, B.D. Qualitative research methodologies: Ethnography. Br. Med. J. 2008, 337, a1020. [CrossRef]

115. Schensul, J.J.; LeCompte, M.D. Essential Ethnographic Methods: A Mixed Methods Approach, 2nd ed.; AltaMira Press: Plymouth, UK, 2012.

116. Bryman, A. Social Research Methods, 3rd ed.; Oxford University Press: New York, NY, USA, 2008.

117. Cohen, L.; Manion, L.; Morrison, K. Research Methods in Education, 8th ed.; Routledge: London, UK, 2017.

118. Schein, E. Organisational Culture and Leadership, 3rd ed.; Jossey-Bass: San Francisco, CA, USA, 2004.

119. Cohen, L.; Manion, L.; Morrison, K. Research Methods in Education, 3rd ed.; Routledge: London, UK, 2011.

120. Spradley, J. Participant Observation; Holt, Rinehart and Winston: New York, NY, USA, 1980.

121. Braun, V.; Clarke, V. Using thematic analysis in psychology. Qual. Res. Psychol. 2006, 3, 77-101. [CrossRef]

122. Merriam, S.B. Qualitative Research: A Guide to Design and Implementation, 3rd ed.; Jossey-Bass: San Francisco, CA, USA, 2009.

123. Silverman, D. Interpreting Qualitative Data, 3rd ed.; Sage Publications: London, UK, 2006.

124. Braun, V.; Clarke, V. Successful Qualitative Research: A Practical Guide for Beginners; Sage: London, UK, 2013.

125. Creswell, J.W. Qualitative Inquiry and Research Design-Choosing among Five Approaches; Sage: London, UK, 2013.

126. Lewins, A. Computer assisted qualitative data analysis (CAQDAS). In Researching Social Life; Gilbert, N., Ed.; SAGE: London, UK, 2008; pp. 394-419.

127. HSE, Health Service Executive. Dealing with Fake Health Information during the Coronavirus Pandemic; 2020. Available online: https:/ / www2.hse.ie/wellbeing/dealing-with-fake-health-information-during-the-coronavirus-pandemic.html (accessed on 10 June 2020).

128. Leach, J.; Driver, R.; Millar, R.; Scott, P. A study of progression in learning about 'the nature of science': Issues of conceptualisation and methodology. Int. J. Sci. Educ. 1997, 19, 147-166. [CrossRef]

129. Bernstein, B. On the classification and framing of educational knowledge. In Knowledge and Control: New Directions for the Sociology of Education; Young, M.F.D., Ed.; Collier-Macmillan: London, UK, 1971; pp. 47-51.

130. DeHaan, G. The development of ESD-related competencies in supportive institutional frameworks. Int. Rev. Educ. 2010, 56, 315-328. [CrossRef]

131. UNESCO. UNESCO Roadmap for Implementing the Global Action Programme on Education for Sustainable Development; UNESCO: Paris, France, 2014. Available online: https:/ / unesdoc.unesco.org/ark:/48223/pf0000230514 (accessed on 4 August 2020).

132. Sterling, S. Separate tracks or real synergy? Achieving a Closer relationship between education and SD, post-2015. J. Educ. Sustain. Dev. 2014, 8, 89-112. [CrossRef]

133. Bybee, R.W. Reforming Science Education: Social Perspectives and Personal Reflections; Teachers College, Columbia University: New York, NY, USA, 1993.

134. Sadler, T.D. Informal reasoning regarding socioscientific issues: A critical review of research. J. Res. Sci. Teach. 2004, 41, 513-536. [CrossRef]

135. Gul, M.D.; Akcay, H. Structuring a new socioscientific issues (SSI) based instruction model: Impacts on pre-service science teachers' (PSTs) critical thinking skills and dispositions. Int. J. Res. Educ. Sci. IJRES 2020, 6, 141-159. [CrossRef]

136. Corcoran, R.P.; O’Flaherty, J.; Xie, C.; Cheung, A.C.K. Conceptualizing and measuring social and emotional learning: A systematic review and meta-analysis of moral reasoning and academic ability, religiosity, political orientation, personality. Educ. Res. Rev. 2020, 30, 1-26. [CrossRef] 
137. O'Flaherty, J.; Gleeson, J. Irish student teachers' levels of moral reasoning: Context, comparisons, and contributing influences. Teach. Teach. 2017, 23, 59-77. [CrossRef]

138. O'Flaherty, J.; Gleeson, J. Longitudinal study of levels of moral reasoning of undergraduate students in an Irish university: The influence of contextual factors. Ir. Educ. Stud. 2014, 33, 57-74. [CrossRef]

139. UNESCO. The Education for Sustainable Development Sourcebook. Education for Sustainable Development in Action, Learning and Training Tools No. 4; UNESCO: Paris, France, 2012.

140. McKeown, R. Education for Sustainable Development Toolkit; 2006. Available online: http://www.esdtoolkit.org/about.htm (accessed on 4 September 2020).

141. Rieckmann, M. Future-oriented higher education: Which key competencies should be fostered through university teaching and learning? Futures 2012, 44, 127-135. [CrossRef]

142. University of Leeds. CHEM2200 Science and Society: The Critical Interface; 2020. Available online: https://leedsforlife.leeds.ac.uk/ Broadening/Module/CHEM2200 (accessed on 12 January 2020).

143. McKeown, R.; Hopkins, C. EE is not equal to ESD: Defusing the worry. Environ. Educ. Res. 2003, 9, 117-128. [CrossRef]

144. DiCarlo, S.E. Too much content, not enough thinking, and too little fun! Adv. Physiol. Educ. 2009, 33, 257-264. [CrossRef] [PubMed]

145. Norris, S.; Philips, L.; Osborne, J. Scientific inquiry: The place of interpretation and argumentation. In Science as Inquiry in the Secondary Setting; Luft, J., Bell, R.L., Gess-Newsome, J., Eds.; NSTA Press: Arlington, VA, USA, 2007; pp. 87-98.

146. Eilks, I. Teaching biodiesel: A sociocritical and problem-oriented approach to chemistry teaching, and students' first views on it. Chem. Educ. Res. Pract. 2002, 3, 67-75. [CrossRef]

147. Belova, N.; Chang-Rundgren, S.N.; Eilks, I. Advertising and science education: A multi-perspective review of the literature. Stud. Sci. Educ. 2015, 51, 169-200. [CrossRef]

148. Colucci-Gray, L.; Camino, E.; Barbiero, G.; Gray, D. From scientific literacy to sustainability literacy: An ecological framework for education. Sci. Educ. 2006, 90, 227-252. [CrossRef]

149. Hodson, D. Science education as a call to action. Can. J. Sci. Math. Technol. Educ. 2010, 10, 197-206. [CrossRef]

150. Bencze, J.L.; Sperling, E.R. Student Teachers as advocates for student-led research-informed socioscientific activism. Can. J. Sci. Math. Technol. Educ. 2012, 12, 62-85. [CrossRef]

151. Erduran, S. Introduction to the focus on ... Scientific practices. Sci. Educ. 2015, 99, 1023-1025. [CrossRef] 